\title{
CHOOSING A PROFESSION AS A MODELING OF THE YOUTH FUTURE (BASED ON SOCIOLOGICAL RESEARCH)
}

\author{
Nina Skosyreva ${ }^{1}$ \\ Vladimir Razumov ${ }^{2}$ \\ Alla Zinich ${ }^{3}$ \\ Vitalii Pomogaev ${ }^{4}$ \\ Yulia Revyakina ${ }^{5}$ \\ Olga Gefner ${ }^{6}$
}

\begin{abstract}
The most important resource in forming human capital is, certainly, the youth, whose mission is not just to reproduce, but also to develop, improve, and update the existing social system. In the article authors are trying to find answers to the following questions: How do contemporary youth see their future? How does this image correlate with the socioeconomic challenges facing contemporary society? What help do young people need in the course of professional selfdetermination? The answers to these questions should be taken into account when developing strategies for the effective use of the human capital of today's youth. Based on the results obtained, the authors conclude that it is necessary to typologize
\end{abstract} behavioral strategy models in the future professional self-determination of young people.

Keywords: youth, professional selfdetermination, choice of profession, behavioral strategies.

\section{Introduction}

At present, one of the main factors in the development of the contemporary innovative economy - the knowledge economy - is human capital, its quality, efficiency, and potential (Abuzyarova et al., 2019). Certainly, the main potential for the development of human capital is youth. According to the famous sociologist and philosopher K. Manheim, youth are "one of

Omsk State Agrarian University named after P.A. Stolypin, Omsk, Russia ${ }^{1}$ Dostoevsky Omsk State University, Omsk, Russia ${ }^{2}$ Omsk State Agrarian University named after P.A. Stolypin, Omsk, Russia ${ }^{3}$ Omsk State Agrarian University named after P.A. Stolypin, Omsk, Russia ${ }^{4}$ Omsk State Agrarian University named after P.A. Stolypin, Omsk, Russia ${ }^{5}$ Omsk State Agrarian University named after P.A. Stolypin, Omsk, Russia ${ }^{6}$ 
the hidden resources that exist in every society, whose mobilization influences its viability ", it is "a revitalizing intermediary, a kind of reserve that comes to the fore when such a revival becomes necessary to adapt to rapidly changing or qualitatively new circumstances" (Mannheim, 1994). An important task facing society and the state is to properly use this innovative potential of the younger generation, to stimulate, and create the necessary conditions for its development and implementation. All this actualizes the study of social well-being, professional self-determination of young people as a factor in the formation of the human capital of the future, especially in the current socio-economic situation of uncertainty, risk-taking, and global challenges.

Professional self-determination is the process of forming a person's attitude to professional activity and a way to implement it through the coordination of personal and socio-professional needs (Professional self-determination, n.d.). Making a professional choice, a young person chooses not only the type of their future occupation but also their lifestyle, place of residence, social circle, social status, that is, in fact, their future. Professional self-determination, therefore, can be represented as modeling of their future, which a young person plans to build, implement in reality, while the profession is a way to implement this model.

\section{Methods}

The research object is students, i.e. youth, who are in an active process of professional self-determination.

The purpose of the research is to identify the value and motivational grounds for professional self-determination, to characterize the image of a future career and the main strategies for the professional development of modern youth.

The main research method is a sociological survey conducted in 2020 at the Omsk State Agrarian University named after P. Stolypin. A questionnaire, including 52 questions of closed, open, or semi-open type was developed for the survey. The research object was University students. The total number of respondents was 1,185 . The study sample was made up of students from the first to the fifth year of seven faculties of full-time and part-time education. Quota-cluster sampling was employed to provide representativeness.

This study summarizes the results of a sociological survey using the tools of categorical-system methodology, which represents a set of methods for analyzing categories and building categorical 
schemes that serve filters for assimilation of information, structures to systematize and visualize it, as well as the basis to create qualitative models of objects (Razumov, 2008). In particular, this study used a crossshaped scheme to analyze the contradictions of professional selfdetermination of young people and typology of their behavioral strategy models in this process. The cruciform scheme of contradictions is built based on identifying and working out a pair of contradictions within the object under study, which simultaneously acts as single dynamic elements of the system, based on which possible conditions of the system are detected.

\section{Results}

Professional self-determination of personality is caused by many factors of both objective and subjective nature, as well as economic, political, and cultural realities of today, and personalpsychological characteristics of a person in a situation of choice. Professional selfdetermination can be represented as a process of movement from the internal resources and capitals of an individual (abilities, interests, values, family traditions, needs) through interaction with external conditions and factors (economic situation, the situation on the labor market) to the formation of their plans, behavioral strategies in building a career and acquiring a professional identity (Didkovskaya, 2017).

The most important component of motivation for professional selfdetermination is the meaning of life values of the individual. They are the most important regulator of human activity, which determines the goals and priorities of the individual, the main areas of their selfimplementation. The conducted research has shown that the axiological basis of modern youth's consciousness concerns the values of family, favorite work, and material welfare. The main priorities of the younger generation are the values of personal and private life, namely, love, family, and children $(78.6 \%$ of respondents). This is quite understandable by the importance of family and personal happiness in a person's life, as well as awareness of family values by young people, on the one hand, and on the other hand, by the age characteristics of the respondents who are in the life span, traditionally involving an active search for their significant other, and marriage. It is also obvious that today's young people are quite pragmatic about their future, realize the importance of work and career in the 
system of life priorities (51.2\%), and strive to achieve material welfare as an important component of success (48.8\%). Moreover, students consider material welfare more important in life than spiritual balance (58.3\% and $48.7 \%$, respectively). It is gratifying, however, that at the same time spiritual values occupy not the last place in the system of value orientations of students. Thus, $43 \%$ of students see education and self-development as a significant goal in their life, while $28.2 \%$ consider creativity as a significant goal. For a third of respondents (33.1\%), freedom and independence are an important basis for life, which well reflects their age peculiarities. At the same time, communicative, hedonistic, and status values occupy the last places in the rating of the meaning of life orientations of modern youth. Socializing with friends is identified as an important life priority by $23.9 \%$ of the respondents; getting pleasure is important for $23.5 \%$ of young people; $13.8 \%$ of students are focused on achieving fame, power, and recognition. Perhaps, this is because active communication in the life of young people is part of their normal way of life, as well as the pleasures that are diverse and easily available nowadays, and therefore are not recognized as a life value.
At that, young people do not think much about glory and power because of their young age.

The respondents who took part in this survey have already chosen the trajectory of their movement to achieve one of the priority life values - a good job and a successful career. They receive professions related to agricultural production, maintenance of this industry, and processing of agricultural products. What is the motivation for their professional choice? The main motive for the professional choice of the young generation is the desire for self-implementation, development of their abilities, and their internal potential. The majority of respondents explain the choice of a future profession by an attractive work (37.4\%), as well as the correspondence of the work to their abilities, knowledge, character, and temper $(18.3 \%)$.

But pragmatic motives in choosing a profession are characteristic of only a small percentage of respondents. Only $11.3 \%$ of young people thought about the demand for their future profession in the labor market, about the prospect of employment, and only $6.6 \%$ of respondents noted the high salary that their future profession could insure. 


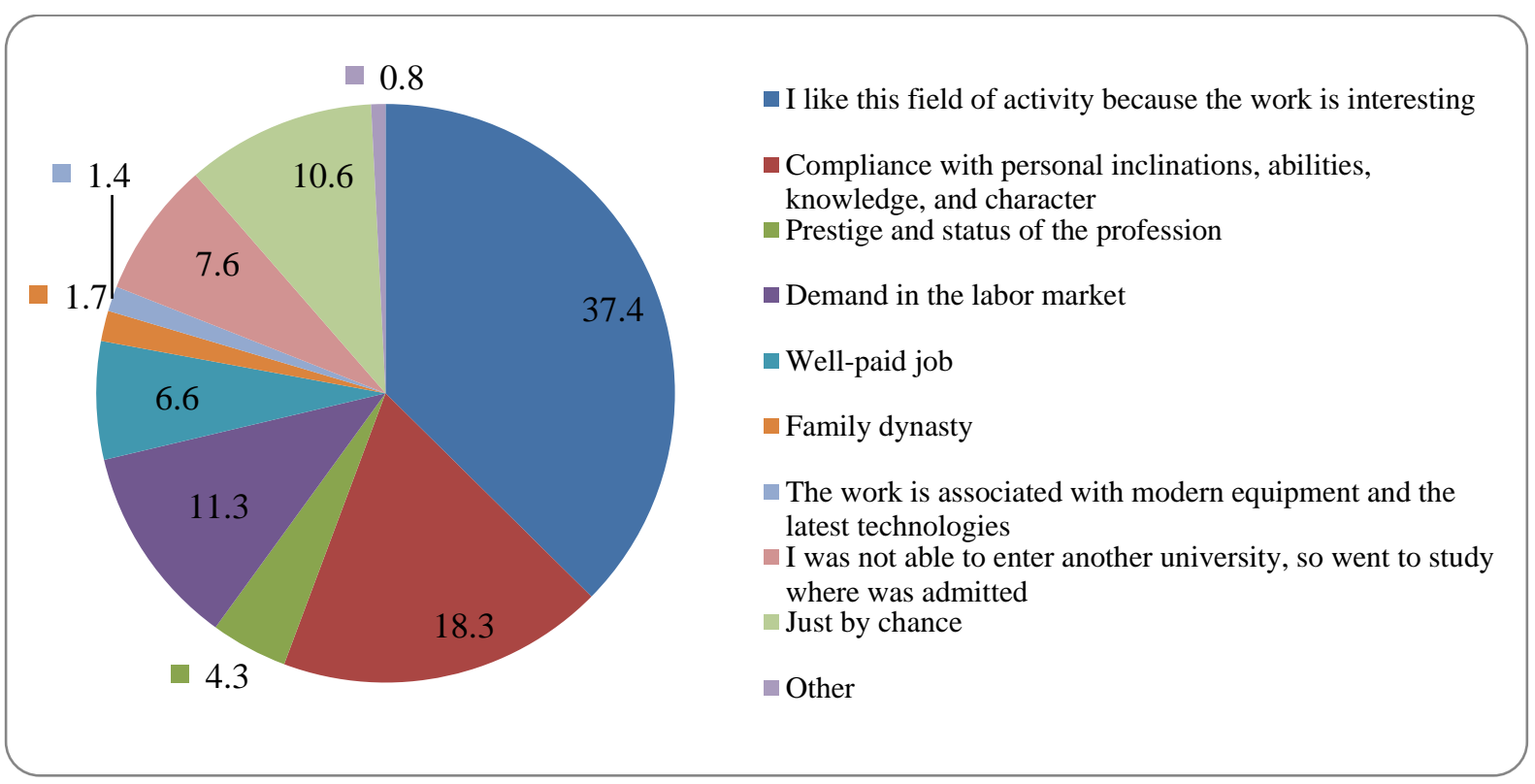

Diagram 1. What is the basis for choosing your future profession?

Obviously, the dominance of internal, personal, individualistic motives in the professional self-determination of young people is a positive point, since, indeed, the future work should be attractive to a person and match his abilities. However, an underestimation by young people of external, social aspects when choosing a future profession (its demand, prestige, wages, innovation, etc.) is quite evident, which is discordant with their sense of life setting on material prosperity and financial well-being. A high proportion of random factors in the choice of profession by modern youth can be considered an alarming symptom. Thus, $10.4 \%$ of respondents noted that their choice was random, while $7.9 \%$ mentioned that they went to study where they were admitted, which can also be considered as a random choice.

Various external factors influence the professional self-determination of young people. Only $22.1 \%$ of respondents noted that nothing influenced their choice. These were young people who have independently decided on their future profession.

The factors that influenced the professional choice of young people include, first of all, the family, i.e. advice and recommendations of parents and relatives. This was stated by $35.6 \%$ of respondents. 


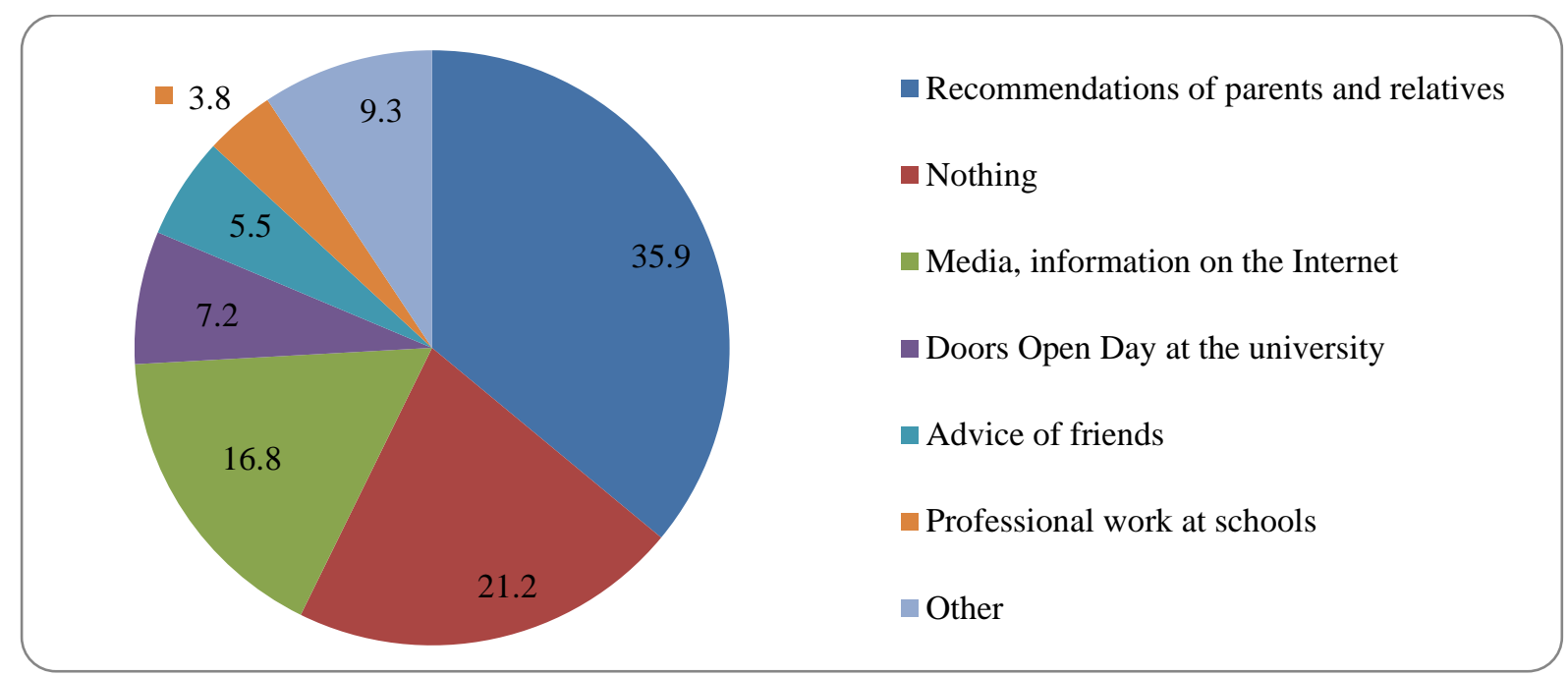

Diagram 2. Which of the following factors influenced the choice of your future profession?

Young people are guided by the life experience of their parents. In general, family traditions, principles, values, and material welfare, certainly, affect the outlook of young people that in the future largely determines their professional choice. What is the family intellectual capital of interviewed respondents? For most of them, parents do not have higher education (54\% of mothers, and $64.2 \%$ of fathers). The majority of young people's parents, namely, $27,2 \%$ are employed in the industrial sector (industry, transport, and construction), $16.3 \%$ work in trade and the service sector, $16.2 \%$ deal with education, culture, and medical institutions, $16.2 \%$ work in agriculture, 6,9\% are engaged in the business, $5.9 \%$ work in administrative fieldwork, and 5,9\% are engaged in households. The majority of respondents $(51.3 \%)$ lived in rural areas before entering the University, while townspeople made up $48.7 \%$. Families generally have an average (43.4\%) and low (41.6\%) income. Thus, the young people interviewed come from families of average or slightly lower social status of corresponding material welfare. For the most part, without having higher education, parents are aware of its importance in the contemporary world as one of the resources of social mobility, encourage their children to get an education in professions that can be actually in demand in the economy of the region with a significant agricultural sector. At that, for respondents, when choosing an educational 
institution, a large role was played not only by the availability of the desired specialty (37.4\%) but also by the availability of statefinanced openings (28.9\%). When choosing education, a significant proportion of respondents were forced to be guided not so much by their interest, quality, or prestige of education, but by its availability.

The information factor is another important factor in shaping the professional preferences of young people. Among the respondents, $16.5 \%$ noted the determining influence of the mass media on their professional choice, $7.2 \%$ stated the importance of the Doors Open Day held by the University in their decision about the chosen profession. The mass media, marketing activities of universities to attract applicants currently have significant impact on the minds of contemporary youth, as well as form images of various professions, fields of activity, professionals competent in a particular field, prestigious and nonprestigious occupations. These images of the profession, however, do not always correspond to the real state of affairs and play a motivating role in the professional self-determination of young people.

The peculiarity of professional self-determination of young people during their student years is that they have already entered this path and made their choice.
This choice is interpreted, approved, or revised in the course of their study at the university. A student becomes more familiar with the chosen profession, gets the required knowledge and skills. The first practical professional experience correlates the image of the profession existing in his mind and reality, assesses his opportunities and prospects. This eventually results either in satisfaction or dissatisfaction with the made choice, confirms professional identity, or causes rejection of the profession (Problemy professional'nogo samoopredeleniya molodezhi: analiz cennostnyh orientacij i professional'nyh strategij, 2011).

The conducted research has shown that most of the young people surveyed are satisfied with their professional choice. The study in the chosen specialty is fully consistent with the life plans of $26.3 \%$ of students, and more or less meets the plans of $55.7 \%$ of students, and only $2.7 \%$ of respondents note the unambiguous disparity of chosen education to plans, while $16.3 \%$ note that the studies mostly do not correspond to their expectations and future intentions. The vast majority of respondents consider their chosen profession interesting and relevant to their abilities $(82.4 \%)$ and are confident in the 
social significance of the chosen profession $(90.7 \%)$.

Today's young people are quite optimistic about the future, confident in their abilities, competitiveness in the labor market, and fairly easy employment. Thus, $14.2 \%$ of respondents believe that it will be easy for them to find a job in their specialty, $68.5 \%$ note that even though it is difficult to find a job in their specialty, it is still possible. At the same time, $25.3 \%$ of young people declare their full readiness for work in their specialty, while $50 \%$ consider that they are mostly ready for work. Probably, shown optimism is due to the youthful stage and lack of experience in searching for a job, ignorance of the real state of affairs in the labor market, because the majority of respondents $(71 \%)$ yet have no working experience. At that, only about a third of the respondents $(34.3 \%)$ plan to work in their specialty after graduation from the university. In the future, young people plan to continue their education $(17.7 \%)$, move to another city or country $(14.3 \%)$, or start their own business $(8.9 \%)$. However, many of the respondents (18.9\%) yet do not know what they will do in the future.

Modern youth are a mobile social group, open to everything new, and ready for change. Young people quite easily change professions, even if in general they are not disappointed in the made professional choice. Thus, $64 \%$ of the respondents are ready to change their profession if the need arises. Moreover, the range of interests of young people in the context of professional self-determination in the future is quite diverse. If they had a choice, the majority of respondents would like to become in the future entrepreneurs and start their own business (45.4\%), some of them would prefer to work in the cultural sector $(28.4 \%)$, in the industrial sphere (27.5\%), in management (26.5\%), and only a few $(17.6 \%)$ young specialists intended to link their professional choice with agriculture, and this why they studied at an agricultural university and had chosen the appropriate specialties. The young generation is also characterized by a fairly high level of potential territorial mobility, readiness to change their place of residence, and build their professional career in a place where young professionals are in demand, offered more prospects, better working conditions, and a larger salary. Only $7 \%$ of respondents plan to return to the village after graduation, even though more than half of them came to study from rural areas and receive agricultural specialties. A large proportion of respondents are students who have decided to stay in Omsk (29.6\%). The certain number of respondents $(10.7 \%)$ 
consider moving to another city (Moscow, Saint Petersburg, Yekaterinburg, Novosibirsk, Kazan, Tyumen, Krasnodar, and Sochi), while some respondents (4.2\%) do not exclude moving to another country (USA, Germany, Norway, Czech Republic, Italy, or Thailand). About a third of students $(34.3 \%)$ have not yet decided on their place of residence and implementation of their career plan. It is obvious that young people tend to move from rural areas to cities, from cities - to large and developing megacities and metropolitan centers searching for better conditions for the implementation of their life plans and professional selfdetermination.

The low proportion of those who want to work in their professions, and the majority's readiness to change their field of activity and place of residence is associated with the establishment of a nonlinear type of career in modern society, flexible professional self-determination, which offers the possibility of changing professional fields, specialization, obtaining additional education, using new emerging opportunities in terms of employment, sensitive response to the needs of the market and society. Currently, in the context of rapidly changing economic and social realities, such flexible strategies in professional self-determination and career-building are an adequate response and optimal adaptation of the younger generation. The globalization of the socioeconomic space, the digitalization of the economy, the importance of the information component, and the focus on innovation in all areas of social practices make new demands on future specialists.

The modern knowledge-based economy requires transprofessionalism, i.e. the ability to perform a wide range of different activities, possessing extensive knowledge and competencies in various professional fields, systemic thinking, project management, customer orientation, and communication skills, creativity, as well as the ability to work in uncertainty and solve nonstandard tasks (Zeer, Symanyuk, 2017). In the current context, education is largely losing its professional character and becoming more general. While studying for a bachelor's degree, students receive general knowledge and skills, the basics of a profession as part of their educational program, but then they can enter the master's program in a completely different profile, radically change the scope of their future activities, and even simultaneously receive a second higher education. Young people often use their initial education and diploma just as a starting point for flexible, nonlinear 
movement along their professional path and career building.

In implementing their future professional plans, young people rely mainly on their own capabilities and resources $(74.3 \%)$, as well as on the assistance of family and friends (15.6\%). However, students expect little from various institutional forms of support in the future. Thus, just $5.2 \%$ of respondents rely on the support of the colleagues at work or organization, while $4.4 \%$ of respondents rely on the state or authorities. Among the personal resources that contribute to future professional success, young people name, first of all, their education $(80 \%$ of the total sample), personal qualities and abilities (78.2\%), good health and external appearance (29.9\%), and personal communications and acquaintances (23.8\%). Among the external factors contributing to career advancement, respondents consider the moral support and personal connections of parents $(29.3 \%)$, as well as the image and the reputation of the university (28.9\%). Although today's youth are generally optimistic and confident about the future, their social well-being is characterized by certain anxiety. Most young people are concerned about unemployment. The respondents believe that unemployment is an adverse and unavoidable consequence of market relations $(31.6 \%)$, see the need to create new jobs to prevent unemployment (38.9\%), and assign the task of controlling unemployment to the state $(17 \%)$. Some respondents $(5.2 \%)$ believe that unemployment increases productivity, and others $(7.3 \%)$ do not have an opinion on this issue. Only $10.9 \%$ of young people are fully contented, and $24.4 \%$ are partially satisfied with the current youth policy, while more than a third of respondents $(33.2 \%)$ are dissatisfied with it, and the rest were not able to answer this question. Thus, young people have a certain distrust of the state in the matter of promoting future professional self-determination, which may be due to the lack of awareness of young people about the forms and methods of such assistance, as well as ignorance of the system of benefits and guarantees.

\section{Discussion}

Professional self-determination of modern youth can be represented using the results obtained in the course of sociological research, and categoricalsystem methodology, through a cruciform configuration of contradictions. 


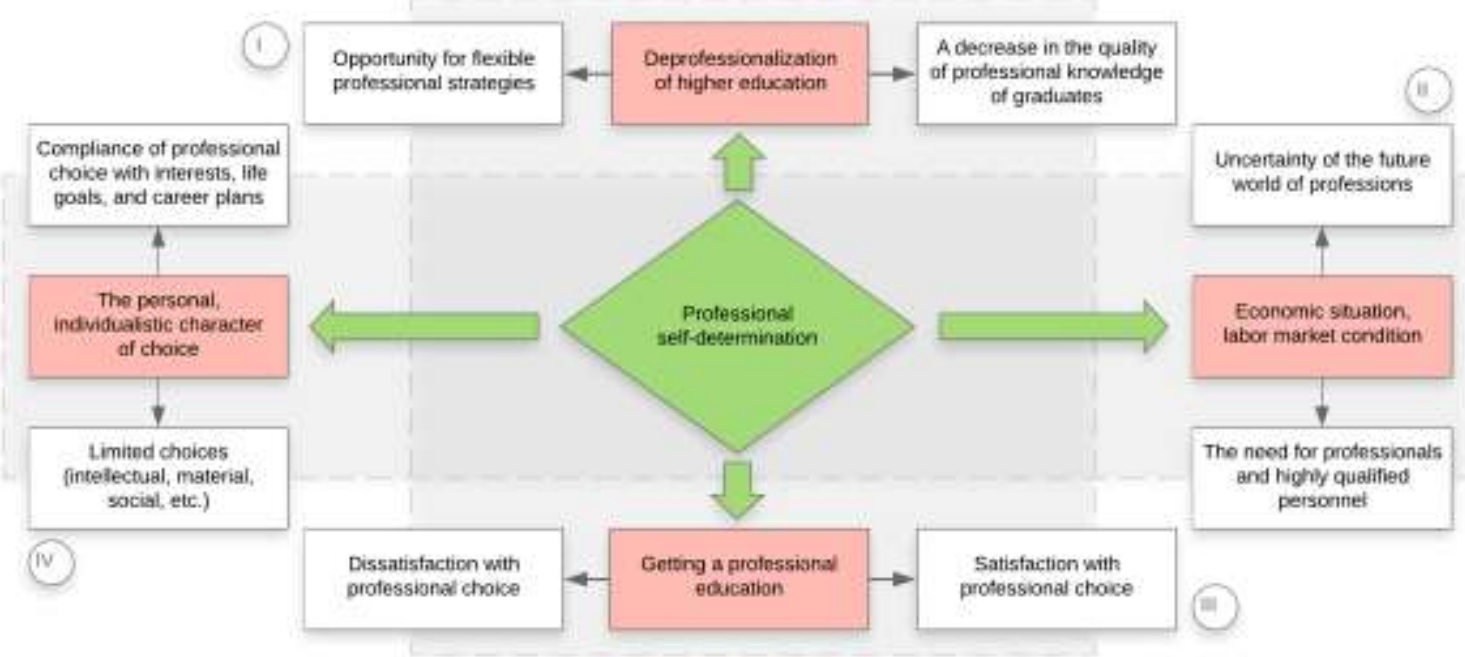

Figure 1. Cruciform configuration of contradictions of professional self-determination of modern youth

One of the main contradictions in the professional self-determination of young people is the contradiction between the personal nature of the choice of future profession and contemporary socioeconomic realities. As shown by the conducted research, young people are dominated by internal personal motivation when choosing a future profession, while the selection process is often carried out without studying and taking into account the real economic situation, market conditions, the needs of the economy for particular specialists, and opportunities for future employment.

At the same time, the process of personal choice of the future professional path is also internally contradictory. On the one hand, young people have certain life goals, and often very ambitious ones, certain interests, talents, worldview, and values, which serve reference points when choosing a profession. On the other hand, the choice of a future profession or educational institution is always limited by the level of required knowledge, material capabilities, abilities, even the character and physical abilities of a person. Therefore, for most young people, choosing a profession is a kind of more or less acceptable and successful compromise between personal interests, desires, goals, and capabilities. Such a position in the professional self- 
determination of young people is quite understandable and natural in a situation of extremely rapidly changing current reality, difficult to predict an uncertain future. The very modern economy and the labor market are developing unstably and inconsistently. On the one hand, in the economic system, any economic sector always needs skilled specialists, professionals in their field. On the other hand, today, it is difficult to imagine what this world of professions will be like in the near future and to predict which professions will be more in demand. It is especially difficult to understand this issue for young, yet not experienced people facing the need to choose.

Another contradiction that arises in the course of professional selfdetermination is related to the existing development trends in modern higher education. A young person makes a professional choice, enters the appropriate educational institution to get a certain profession, with which he decided to associate his future. But at the same time, he faces the consequences of deprofessionalization of higher education, with its transformation to a greater extent simply into higher general education. The contemporary education system opens up significant opportunities for young people to implement their professional strategies. Today, higher education is most often considered by young people as a social elevator, a kind of key that opens up a lot of alternative opportunities in the future, rather than means of acquiring a certain profession. The downside of this trend, however, is a decrease in motivation to obtain proper professional knowledge, and deterioration in knowledge quality among graduates. While studying at an educational institution, getting to know their future profession more closely, a young person eventually accepts it and feels satisfied with their professional choice, or experiences disappointment.

\section{Conclusion}

Based on the above presented cruciform configuration of contradictions, the authors developed a typology of behavioral strategy models in the future professional selfdetermination of young people which is as follows.

The $1^{\text {st }}$ type. Young people, mobile and ready to use flexible strategies, who have chosen a profession corresponding to their life priorities, values, and interests, will choose a 
nonlinear type of career within their chosen profession.

The $2^{\text {nd }}$ type. Young people with low quality of professional knowledge and skills in a situation of socioeconomic uncertainty will be poorly competitive in the labor market, doomed to professional degradation, and unskilled labor.

The $3^{\text {rd }}$ type. Young people who are satisfied with their professional choice in the current economic need for highly qualified personnel, professionals, are predisposed to implement a linear type of career within the scope of their profession.

The $4^{\text {th }}$ type. Young people who were forced to choose a profession based on their limited opportunities, current circumstances, dissatisfied with the choice, will prefer to reorient, leave the profession, and change the field of activity.

\section{Acknowledgments}

The study was funded by the Russian Foundation for Basic Research (RFBR), project No. 19-29-07366.

\section{References:}

Abuzyarova, D., Belousova, V.,
Krayushkina, Zh., Lonshcikova, Y., Nikiforova, E., Chichkanov, N. (2019). The role of human capital in science, technology, and innovation. Foresight and STI Governance, 13(2), 107-119. Mannheim, K. (1994). Diagnosis of our time. Moscow: Lawyer.

Professional self-determination. Pedagogical Terminological Dictionary. Retrieved from: https://pedagogical_dictionary.academic $. \mathrm{ru} / 2628 /$

Razumov, V.I. (2008). Kategorial'nosistemnaya metodologiya $\mathrm{v}$ podgotovke uchenyh [Categorical-system methodology in the training of scientists]. Omsk: Omsk State University.

Didkovskaya, Ya.V. (2017). Professional'noe samoopredelenie studenchestva Sverdlovskoj oblasti: teoreticheskie podhody, problemy, dinamika [Professional selfdetermination of students of the Sverdlovsk Region: theoretical approaches, problems, dynamics]. Bulletin of the Surgut State Pedagogical University, 5, 212.

Problemy professional'nogo samoopredeleniya molodezhi: analiz cennostnyh orientacij i professional'nyh strategij [Problems of professional self- 
determination of youth: Analysis of value orientations and professional strategies]: information and analytical report. (2011). Yekaterinburg: Ural Federal University.

Zeer, E.F., Symanyuk, E.E. (2017). Metodologicheskie orientiry razvitiya transprofessionalizma pedagogov professional'nogo obrazovaniya [Methodological guidelines for the development of transprofessional model of professional education teachers]. Education and Science, 19(8), 12 